J. Environ. Sci.

Institute of Environmental Studies and Research - Ain Shams University

\title{
EFFECT OF THE DIFFERENT ENVIRONMENT FACTORS THE GROUNDWATER CHARACTERISTICS AT EL-SADAT CITY - EGYPT
}

\author{
Nora A. M. Abdel-Rahman ${ }^{(1)}$; Taha A. M. Abdel Razek ${ }^{(1)}$ \\ and Yahia R. Gedamy ${ }^{(2)}$
}

1) Institute of Environmental Studies and Research, Ain Shams University, Cairo, Egypt 2) Desert Research Center, Cairo, Egypt

\begin{abstract}
This work aims to evaluate the pollution hazards of surface and groundwater at El-Sadat City, Egypt. Forty-five water samples were collected from the surface water bodies (El-Nasery canal and the oxidation ponds) and groundwater samples at the study area. The chemical composition of the water resources at El-Sadat city was outlined through out determination of $\mathrm{pH}, \mathrm{EC}, \mathrm{TDS}$, major cations and anions. The pollution of the collected water samples was evaluated based on determination of minor elements, trace and soluble heavy metals as well as biological and bacteriological pollutants

Results revealed that all surface water samples (El-Nasery canal) and the majority of the groundwater samples (93\%) in the study area are fresh water, while the rest of the groundwater samples $(7 \%)$ are brackish water. All surface water and majority of the groundwater samples (90\%) are suitable for drinking as they have a salinity as well as nitrite, nitrate, phosphate and trace constituents less than the permissible limits as well as their low contents from faecal Coliforms. The rest of the groundwater samples $(10 \%)$ are unsuitable for drinking as they have nitrite, nitrate, phosphate and trace constituents higher than the permissible limits as well as their high contents from faecal Coliforms.
\end{abstract}

Key words: Water chemistry, water pollution, water evaluation, El-Sadat City. 


\section{INTRODUCTION}

El-Sadat City is considered as one of the biggest and important industrial city in Egypt. It has been established more than four decades ago at about $80 \mathrm{~km}$ northwest of Cairo along the Cairo - Alexandria desert road. The study area is bounded by latitudes $30^{\circ} 18^{\prime} \& 30^{\circ} 30^{\prime} \mathrm{N}$ and longitudes $30^{\circ} 30^{\prime} \& 30^{\circ}$ 50 E. The total area of El-Sadat city is about $500 \mathrm{~km}^{2}$ (Fig.1).

The groundwater is considered the main source of water for drinking, agriculture and industrial activities. Great attention is being paid to the aquifers in this area because its high water content and good quality due its mainly recharged from the Nile Delta fresh aquifer.

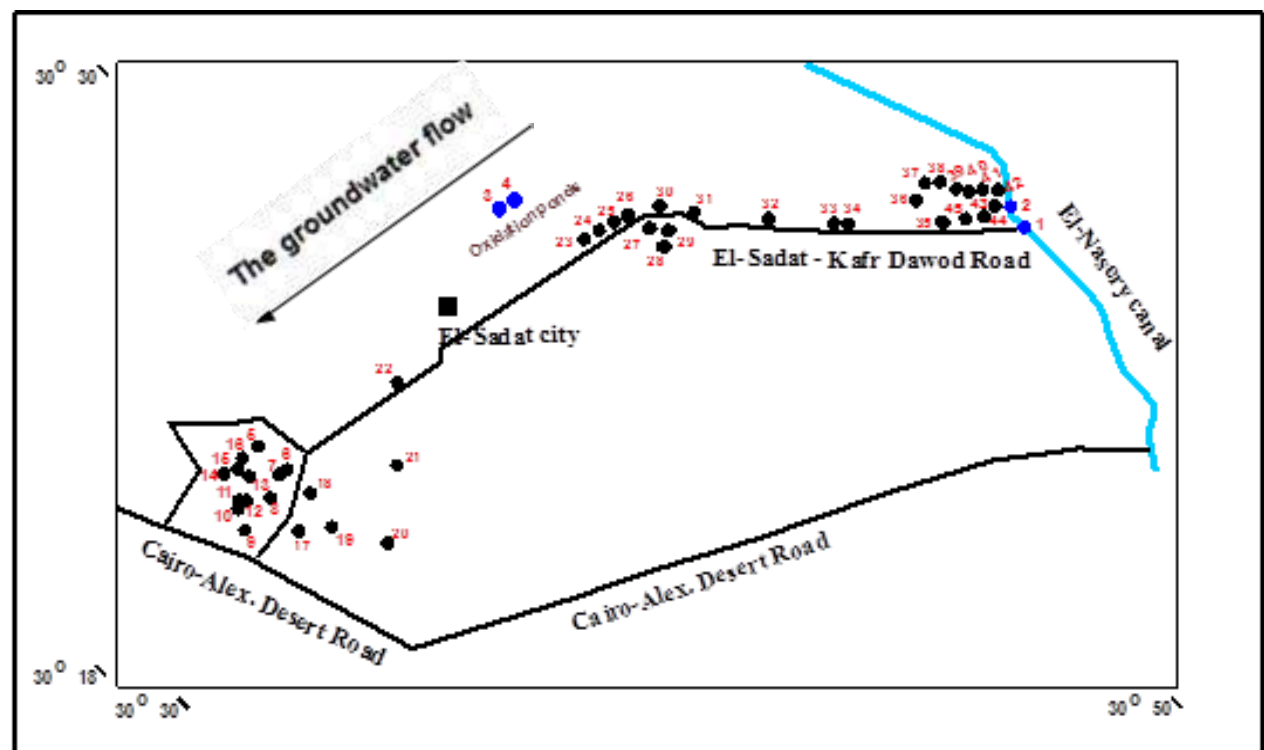

Fig. (1): The water samples sites map

There are more than 94 factories of chemicals and metallurgy industries at El-Sadat city (El-Tahawy et al.,2006). Also, it was noticed that the nearest 
fresh drinking water source for El-Sadat city is El-Nasery canal that is located at 25km east of El-Sadat city (Badway et al., 2016).

There are two wastewater ponds (oxidation ponds) at El-Sadat city are used for collection domestic, agricultural and industrial waste materials via a network of pipelines. Wastewater contains many polluted materials which may be penetrated down to the Pleistocene aquifer and negatively affect the water quality. From the climatic view, the area under investigation belong to the semi-arid region, where it is characterized by hot and dry weather in the summer and mild to cold weather in winter.

Great attention paid to its aquifer due to its high water content and good quality as it mainly recharged from the Nile Delta fresh aquifer. The water resources in the study area divided into surface water and groundwater; the surface water represented by El-Nasery canal, which extended from northeast to north the study area. While the groundwater represented by the Pleistocene aquifer, which is the main groundwater reservoir in El-Sadat city and almost all the productive wells tap this aquifer to yield the water needed for domestic, agricultural and industrial activities. Minor feeding also comes from rainfall and surface infiltration.

The aim of this study is to identify the chemical and microbial pollution of surface water (El-Nasery canal) and groundwater samples at El-Sadat city as well as their suitability for the different purposes.

\section{MATERIALS and METHODS}

A total number of forty-five (45) water samples were collected from ElSadat city during 2017 and their locations was determined in situ using a GPS 
instrument model (Magellan Nave 5000 Pro), four surface water samples representing both El-Nasery canal and the oxidation ponds as well as fortyone samples representing the aquifer groundwater in the study area. These water samples were collected and brought back to the lab and kept in refrigerator for analyses.

The collected water samples were divided into five parts to determine five kinds of analyses. The first kind is the measurement of $\mathrm{EC}, \mathrm{pH}$ and major cations $\left(\mathrm{Na}^{+}, \mathrm{K}^{+}, \mathrm{Ca}^{2+}\right.$ and $\left.\mathrm{Mg}^{2+}\right) \&$ anions $\left(\mathrm{Cl}^{-}, \mathrm{CO}_{3}{ }^{2-}, \mathrm{HCO}_{3}{ }^{-}\right.$and $\left.\mathrm{SO}_{4}{ }^{2-}\right)$ as well as $\mathrm{SiO} 2$ according to Rainwater and Thatcher (1960). The second kind includes the measurement of minor constituents $\left(\mathrm{NH}_{3}, \mathrm{NO}_{2}{ }^{-}, \mathrm{NO}_{3}{ }^{-}, \mathrm{PO}_{4}{ }^{3-}\right.$ and B) according to Fishman and Friedman (1985).The third kind of analyses can be done by acidifying the collected samples in situ by adding drops of $\mathrm{HNO}_{3}$ acid for the measurement of trace elements and soluble heavy metals (Al, Fe, $\mathrm{Zn}, \mathrm{Mn}, \mathrm{Cu}, \mathrm{Ni}, \mathrm{Cd}, \mathrm{Pb}, \mathrm{Cr}, \mathrm{Co}$ and $\mathrm{Ba}$ ) using Inductive coupled plasma Mass spectroscopy, ICP -MS) according to APHA, 1989. The fourth kind is the measurement of the biological oxygen demands (BOD) and chemical oxygen demands (COD) as well as total organic carbon (TOC) according to APHA, 1989. The fifth kind is the measurement of microbial contamination that performed within 24 hours of collection the water samples from the field using standard Multiple Tube Fermentation Technique for the determination of the Most Probable Number (MPN) index using double and single strength Bromo - Cresol Purple MacConkey medium while, for detection E. Coli and Salmonella sp., a yellow collar colony on filter membrane at $44^{0} \mathrm{C}$ was produced. For differentiation the different species of the enteric bacteria, sub- 
J. Environ. Sci.

Institute of Environmental Studies and Research - Ain Shams University

culturing colonies on Triple Sugar Iron (TSI) were done for the contaminated water samples according to APHA, 1989.

\section{RESULTS AND DISCUSSION}

\section{I- Chemical characteristics of the surface water and groundwater} samples in the study area: The chemical characteristics of the surface water and groundwater in the study area were investigated through the discussion of the water salinity and hypothetical salts.

3.I.1-Water salinity: The total dissolved solids (TDS) are a measure of total mass ions dissolved in water. Different methods used for water classification corresponding to its salinity values.

According to Chebotarev (1955), the natural water is classified under three main categories of total salinity as follows; fresh water $<1500 \mathrm{mg} / \mathrm{l}$, brackish water $1500-5000 \mathrm{mg} / \mathrm{l}$ and saline water $>5000 \mathrm{mg} / \mathrm{l}$.

The TDS values for surface water samples (El-Nasery canal) range from $265-283 \mathrm{mg} / \mathrm{l}$ and vary between $4000-4863 \mathrm{mg} / \mathrm{l}$ for drainage water (oxidation ponds), while for groundwater samples, the TDS values vary between 241 (well No. 33) to $2098 \mathrm{mg} / \mathrm{l}$ (well No. 15), Table (1) and Fig. (2).Based on Chebotarev classification, it is clear that the majority of the groundwater samples (93\%) in the study area belong to fresh zone and the rest of the sample $(7 \%)$ belong to the brackish zone.

The groundwater samples that located in the fresh zone may be affected by the seepage from El-Nasery canal, while that located in the brackish zone may be affected by the agricultural and industrial activities. 
3.I.2-Hypothetical Salt Combination: Hypothetically, the ions of the strong acids $\left(\mathrm{Cl}^{-}\right.$and $\left.\mathrm{SO}_{4}{ }^{2-}\right)$ form chemical combinations with alkalis $\left(\mathrm{Na}^{+}\right.$and $\left.\mathrm{K}^{+}\right)$ and the rest of the acid radical's combing with the alkaline earth's $\left(\mathrm{Ca}^{2+}\right.$ and $\left.\mathrm{Mg}^{2+}\right)$. If the cations of alkalis and alkaline earth's are in surplus in the water, they will combine with weak acids $\left(\mathrm{HCO}_{3}{ }^{-}\right)$. The combination between major anions and cations reveals the formation of one group of hypothetical salt combination for both rain water and Nile River water, and three groups of hypothetical salts combinations for surface water and aquifer groundwater samples (Table 2).

Table (1): The concentration of the major constituents in the surface water and groundwater samples at the study area as $\mathrm{mg} / \mathrm{l}(\mathrm{ppm})$

\begin{tabular}{|c|c|c|c|c|c|c|c|c|c|c|c|c|c|}
\hline \multirow{2}{*}{$\begin{array}{c}\text { Serial } \\
\text { No. }\end{array}$} & \multirow{2}{*}{$\begin{array}{c}\text { Sample } \\
\text { No. }\end{array}$} & \multirow{2}{*}{ pH } & \multirow{2}{*}{$\begin{array}{c}\text { EC } \\
\text { (us/cm) }\end{array}$} & \multirow{2}{*}{$\begin{array}{c}\text { TDS } \\
(\mathrm{mg} / \mathrm{l})\end{array} \mid$} & \multicolumn{4}{|c|}{ Soluble cations as ppm } & \multicolumn{4}{|c|}{ Soluble anions as ppm } & \multirow{2}{*}{$\begin{array}{c}\mathrm{SiO}_{2} \\
(\mathrm{mg} / \mathrm{l})\end{array}$} \\
\hline & & & & & $\mathrm{Ca}^{2+}$ & $\mathbf{M g}^{2+}$ & $\mathrm{Na}^{+}$ & $\mathbf{K}^{+}$ & $\mathrm{CO}_{3}{ }^{2-}$ & $\mathrm{HCO}_{3}^{-}$ & $\mathbf{C I}^{-}$ & $\mathrm{SO}_{4}{ }^{2-}$ & \\
\hline \multicolumn{14}{|c|}{ Surface water samples } \\
\hline \multicolumn{14}{|c|}{ El-Nasery Canal } \\
\hline 1 & 34 & 7.11 & 462 & 265 & 45.5 & 10.3 & 31.5 & 5.08 & - & 121.4 & 40.4 & 72.0 & 0 \\
\hline 2 & 36 & 7.10 & 474 & 283 & 36.7 & 14.8 & 36.6 & 5.47 & - & 74.4 & 47.5 & 104.7 & 0 \\
\hline \multicolumn{14}{|c|}{ Drainage water samples (Oxidation ponds) } \\
\hline 3 & 13 & 7.01 & 7410 & 4863 & 790.6 & 72.0 & 884.5 & 53.95 & - & 210.5 & 2797.8 & 158.9 & 0.8817 \\
\hline 4 & 14 & 4.40 & 5590 & 4000 & 776.4 & 80.4 & 507.4 & 53.17 & - & 28.7 & 2010.6 & 557.5 & 6.554 \\
\hline \multicolumn{14}{|c|}{ Groundwater samples } \\
\hline 5 & 1 & 7.24 & 1210 & 727 & 68.7 & 29.5 & 141.2 & 5.47 & - & 104.3 & 194.3 & 235.8 & 2.940 \\
\hline 6 & 2 & 7.09 & 1955 & 1134 & 90.5 & 32.1 & 280.1 & 8.21 & - & 137.9 & rYq,r & 425.1 & 3.046 \\
\hline 7 & 3 & 7.19 & 2340 & 1462 & 114.0 & 41.6 & 324.1 & 7.82 & - & 69.6 & 366.0 & 573.5 & 2.968 \\
\hline 8 & 4 & 7.12 & 526 & 335 & 37.5 & 4.5 & 67.2 & 5.30 & - & 45.8 & 52.8 & 145.1 & 2.841 \\
\hline 9 & 5 & 7.47 & 482 & 275 & 36.7 & 8.9 & 49.7 & 3.91 & - & 111.7 & 67.4 & 52.4 & 3.031 \\
\hline 10 & 6 & 7.13 & 1599 & 946 & 133.1 & 35.35 & 143.5 & 8.21 & - & 101.3 & 317.7 & 257.9 & 2.990 \\
\hline 11 & 7 & 7.10 & 1943 & 1186 & 114.0 & 29.7 & 254.4 & 9.38 & - & 99.5 & 357.4 & 371.3 & 2.997 \\
\hline 12 & 8 & 7.13 & 2140 & 1069 & \begin{tabular}{|l|}
197.8 \\
\end{tabular} & 21.8 & 218.0 & 10.16 & - & 109.2 & 458.2 & 321.3 & 3.015 \\
\hline 13 & 9 & 7.33 & 549 & 315 & 39.9 & 8.0 & 60.9 & 7.43 & - & 121.4 & \begin{tabular}{|l|}
84.8 \\
\end{tabular} & 53.3 & 2.736 \\
\hline 14 & 10 & 7.37 & 453 & 269 & 36.5 & 3.6 & 53.4 & 3.13 & - & 92.7 & 51.8 & 74.4 & 2.661 \\
\hline 15 & 11 & 7.00 & 3450 & 2098 & 220.6 & 72.1 & 397.4 & 10.95 & - & 103.1 & 648.9 & 696.9 & 2.779 \\
\hline
\end{tabular}


J. Environ. Sci.

Institute of Environmental Studies and Research - Ain Shams University

Cont. table (1): The concentration of the major constituents in the surface water and groundwater samples at the study area as $\mathrm{mg} / \mathrm{l}(\mathrm{ppm})$

\begin{tabular}{|c|c|c|c|c|c|c|c|c|c|c|c|c|c|}
\hline \multirow{2}{*}{$\begin{array}{c}\text { Serial } \\
\text { No. }\end{array}$} & \multirow{2}{*}{$\begin{array}{c}\text { Sample } \\
\text { No. }\end{array}$} & \multirow{2}{*}{ pH } & \multirow{2}{*}{$\begin{array}{c}\text { EC } \\
\text { (us/cm) }\end{array}$} & \multirow{2}{*}{$\begin{array}{c}\text { TDS } \\
(\mathrm{mg} / \mathrm{l})\end{array}$} & \multicolumn{4}{|c|}{ Soluble cations as ppm } & \multicolumn{4}{|c|}{ Soluble anions as ppm } & \multirow{2}{*}{$\begin{array}{c}\mathrm{SiO}_{2} \\
(\mathrm{mg} / \mathrm{l})\end{array}$} \\
\hline & & & & & $\mathrm{Ca}^{2+}$ & $\mathbf{M g}^{2+}$ & $\mathrm{Na}^{+}$ & $\mathbf{K}^{+}$ & $\mathrm{CO}_{3}{ }^{2-}$ & $\mathrm{HCO}_{3}^{-}$ & $\mathrm{CI}^{-}$ & $\mathrm{SO}_{4}{ }^{2-}$ & \\
\hline \multicolumn{14}{|c|}{ Groundwater samples } \\
\hline 16 & 12 & 7.00 & 3090 & 1916 & 183.8 & 58.0 & 385.0 & 8.99 & - & 67.1 & 250.2 & 726.7 & 3.107 \\
\hline 17 & 15 & 7.00 & 1310 & 836 & 83.8 & 36.2 & 132.5 & 7.04 & - & 36.6 & 118.4 & 440.0 & 3.614 \\
\hline 18 & 16 & 7.60 & 502 & 299 & 45.7 & 13.9 & ro,r & 2.74 & - & 83.6 & 45.4 & 114.3 & 3.117 \\
\hline 19 & 17 & 7.56 & 558 & 349 & 57.1 & 6.9 & 47.6 & 3.13 & - & 51.9 & 52.5 & 155.6 & 3.366 \\
\hline 20 & 18 & 7.60 & 432 & 245 & 32.5 & 13.1 & 35.4 & 3.13 & - & 82.4 & 28.3 & 91.3 & 2.660 \\
\hline 21 & 19 & 7.38 & 752 & 455 & 58.5 & 17.8 & 69.5 & 4.69 & - & 89.1 & 87.9 & 172.0 & 3.474 \\
\hline 22 & 20 & 7.43 & 558 & 331 & 46.5 & 16.2 & 41.2 & 5.47 & - & 81.1 & 660. & 115.3 & 1.141 \\
\hline 23 & 21 & 7.25 & 1001 & 599 & 84.0 & 25.5 & 81.6 & 6.65 & - & 106.8 & 138.7 & 208.9 & 3.64 \\
\hline 24 & 22 & 7.26 & 1171 & 699 & 121.6 & 13.9 & 99.4 & 7.36 & - & 115.9 & 204.3 & 194.5 & 3.27 \\
\hline 25 & 23 & 7.42 & 720 & 435 & 65.1 & 13.1 & 63.7 & 5.86 & - & 88.5 & 102.5 & 140.2 & 3.318 \\
\hline 26 & 24 & 7.12 & 2500 & 1584 & 125.9 & 40.5 & $r \leqslant q, \tau$ & 7.36 & - & 135.4 & 94.3 & 966.04 & 3.753 \\
\hline 27 & 25 & 7.18 & 1362 & 799 & 87.0 & 26.4 & $17 ., 1$ & 5.86 & - & 94.6 & 167.0 & 353.0 & 3.321 \\
\hline 28 & 26 & 7.25 & 578 & 347 & 51.5 & 24.3 & 25.5 & 5.30 & - & 52.6 & 64.9 & 148.9 & 4.070 \\
\hline 29 & 27 & 7.15 & 1216 & 758 & 100.6 & 24.4 & 110.2 & 6.25 & - & 81.8 & 123.4 & 352.5 & 3.354 \\
\hline 30 & 28 & 7.24 & 1929 & 1229 & 110.2 & 37.6 & 241.7 & 7.43 & - & 125.7 & 165.6 & 603.3 & 4.324 \\
\hline 31 & 29 & 7.33 & 641 & 387 & 67.7 & 16.3 & 34.5 & 3.91 & - & 81.8 & 57.1 & 166.7 & 3.304 \\
\hline 32 & 30 & 6.65 & 1130 & 725 & 101.8 & 27.5 & 86.9 & 7.04 & - & 34.2 & 87.9 & 396.3 & 3.222 \\
\hline 33 & 31 & 7.40 & 412 & 241 & 36.1 & 7.3 & 37.3 & 3.91 & - & 91.5 & 42.6 & 68.2 & 3.040 \\
\hline 34 & 32 & 7.19 & 2370 & 1162 & 201.6 & 52.4 & 209.8 & 8.21 & - & 87.9 & 346.5 & 299.9 & 3.476 \\
\hline 35 & 33 & 7.15 & 336 & 187 & 37.5 & 7.5 & 17.9 & 3.91 & - & 94.6 & 39.7 & 33.1 & 3.694 \\
\hline 36 & 35 & 7.13 & 339 & 196 & 30.3 & 10.9 & 20.0 & 5.30 & - & 73.8 & 34.0 & 58.6 & 1.243 \\
\hline 37 & 37 & 7.09 & 700 & 354 & 67.5 & 20.4 & 40.7 & 6.65 & - & 123.2 & 57.4 & 161.4 & 2.740 \\
\hline 38 & 38 & 7.01 & 1171 & 703 & 100.0 & 28.3 & 92.3 & 6.25 & - & 61.0 & 108.5 & 367.4 & 3.093 \\
\hline 39 & 39 & 7.70 & 900 & 579 & 109.6 & 14.2 & 49.9 & 7.04 & - & 23.8 & 77.7 & 308.4 & 2.873 \\
\hline 40 & 40 & 7.41 & 1425 & 403 & 92.0 & 21.5 & 177.3 & 7.43 & - & 108.0 & 125.2 & 429.9 & 2.644 \\
\hline 41 & 41 & 7.25 & 610 & 342 & 63.5 & 14.5 & 36.6 & 5.87 & - & 145.2 & 137.8 & \begin{tabular}{|l|}
11.0 \\
\end{tabular} & 3.066 \\
\hline 42 & 42 & 7.11 & 1054 & 621 & 108.6 & 16.5 & 81.4 & 8.60 & - & 192.8 & 128.4 & 180.6 & 2.861 \\
\hline 43 & 43 & 7.05 & 1342 & 839 & 148.3 & 19.0 & 97.3 & 8.99 & - & 71.4 & 165.6 & 364.1 & 2.574 \\
\hline 44 & 44 & 7.13 & 1162 & 701 & 106.6 & 30.2 & 83.7 & 7.43 & - & 130.0 & 135.8 & 272.3 & 2.984 \\
\hline 45 & 45 & 7.31 & 651 & 387 & 74.85 & 18.1 & 35.4 & 4.69 & - & 114.1 & 74.1 & 122.5 & 3.446 \\
\hline
\end{tabular}


Table (2): Hypothetical salts combinations of surface water and groundwater samples in the study area

\begin{tabular}{|c|c|c|}
\hline Assemblages & "Hypothetical salts combinations & $\%$ \\
\hline \multicolumn{3}{|c|}{ Rain water } \\
\hline I & $\begin{array}{c}\mathrm{NaCl}, \mathrm{Na}_{2} \mathrm{SO}_{4}, \mathrm{NaHCO}_{3}, \mathrm{Mg}\left(\mathrm{HCO}_{3}\right)_{2} \text { and } \\
\mathrm{Ca}\left(\mathrm{HCO}_{3}\right)_{2}\end{array}$ & 100 \\
\hline \multicolumn{3}{|c|}{ Nile River } \\
\hline II & $\begin{array}{c}\mathrm{NaCl}, \mathrm{Na} 2 \mathrm{SO}_{4}, \mathrm{MgSO}_{4}, \mathrm{Mg}\left(\mathrm{HCO}_{3}\right)_{2} \text { and } \mathrm{Ca} \\
\left(\mathrm{HCO}_{3}\right)_{2}\end{array}$ & 100 \\
\hline \multicolumn{3}{|c|}{ El-Nasery canal } \\
\hline III & $\mathrm{NaCl}, \mathrm{Na}_{2} \mathrm{SO}_{4}, \mathrm{MgSO}_{4}, \mathrm{CaSO}_{4}$ and $\mathrm{Ca}\left(\mathrm{HCO}_{3}\right)_{2}$ & 100 \\
\hline \multicolumn{3}{|c|}{ Drainage water samples (oxidation ponds) } \\
\hline IV & $\mathrm{NaCl}, \mathrm{MgCl}_{2}, \mathrm{CaCl}_{2}, \mathrm{CaSO}_{4}$ and $\mathrm{Ca}\left(\mathrm{HCO}_{3}\right)_{2}$ & 100 \\
\hline \multicolumn{3}{|c|}{ Groundwater samples } \\
\hline III & $\mathrm{NaCl}, \mathrm{Na}_{2} \mathrm{SO}_{4}, \mathrm{MgSO}_{4}, \mathrm{CaSO}_{4}$ and $\mathrm{Ca}\left(\mathrm{HCO}_{3}\right)_{2}$ & 68 \\
\hline II & $\mathrm{NaCl}, \mathrm{Na}_{2} \mathrm{SO}_{4}, \mathrm{MgSO}_{4}, \mathrm{Mg}\left(\mathrm{HCO}_{3}\right)_{2}$ and $\mathrm{Ca}\left(\mathrm{HCO}_{3}\right)_{2}$ & 5 \\
\hline IV & $\mathrm{NaCl}, \mathrm{MgCl}_{2}, \mathrm{CaCl}_{2}, \mathrm{CaSO}_{4}$ and $\mathrm{Ca}\left(\mathrm{HCO}_{3}\right)_{2}$ & 7 \\
\hline $\mathrm{V}$ & $\mathrm{NaCl}, \mathrm{MgCl}_{2}, \mathrm{MgSO}_{4}, \mathrm{CaSO}_{4}$ and $\mathrm{Ca}\left(\mathrm{HCO}_{3}\right)_{2}$ & 20 \\
\hline
\end{tabular}

As shown in table (2), the presence of the hypothetical salts assembles (II and III) in $73 \%$ of the groundwater samples in the study area indicates that the majority of the groundwater samples in the study area are affected by ElNasery canal water, i.e., there are seepage from the canal water to the groundwater. On the other hand, the rest of the groundwater samples $(27 \%)$ have the assemblages (IV and V), which means that some groundwater samples in the study area are affected by the oxidation ponds and the effluents of the industrial factories as well as the return flow after irrigation. In addition, the presence of the hypothetical salts assembles (II and III) indicates that the leaching and the dissolution process for groundwater from the aquifer 
matrices., while the presence of hypothetical salts (IV and V) indicates the seepage of the drainage water from the oxidation ponds to the groundwater.

3.2-Water pollution: Pollution of water is discussed on the basis of determining the inorganic, biological and microbial pollutants analyses regarding to the recommended level of contamination, according to Egyptian Higher Committee for Water (1997) and WHO (2011).

Water pollution is a main cause of deaths and diseases worldwide. It is considered the world's biggest health risk, threaten not only humans, but also myriad other plants and animals that rely on water to live. The rapid extension of the industrial development countries was accompanied of pollution, especially due to wastewater discharged from factories.

\subsection{1-Chemical inorganic pollutants}

3.2.1.1-Trace elements and soluble heavy metals contamination: The concentration of some trace and soluble heavy metals are illustrated in table (3).

The obtained data show high variability among the measured trace elements, where some of them are less than safe limits for all the water samples, while the other show higher concentrations more than the permissible limits in some of the water samples.

It is noticed that all surface water samples (El-Nasery canal) have $\mathrm{Al}, \mathrm{Cr}$, $\mathrm{Cu}, \mathrm{Mn}, \mathrm{Ni}, \mathrm{Pb}, \mathrm{Zn}, \mathrm{B}, \mathrm{Cd}, \mathrm{Cu}$ and $\mathrm{Ba}$ concentrations less than the permissible limits for contamination. On the other hand, all groundwater samples have $\mathrm{Al}, \mathrm{Cu}, \mathrm{Ni}, \mathrm{Pb}, \mathrm{B}, \mathrm{Cd}, \mathrm{Cu}$ and $\mathrm{Ba}$ concentrations less than the permissible limits for contamination. For $\mathrm{Cr}, \mathrm{Fe}, \mathrm{Mn}$ and $\mathrm{Zn}$, the data showed 
that the concentrations less than the permissible limts were 98, 61, 88 and 68 $\%$, respectively.

3.2.1.2- Nitrogen compounds: This form of pollutants includes the study the concentration of nitrogen compounds $\left(\mathrm{NH}_{3}, \mathrm{NO}_{2}{ }^{-}, \mathrm{NO}_{3}{ }^{-}\right.$and total $\mathrm{N}$ forms) and $\mathrm{PO}_{4}{ }^{3-}$ (Table 4).

The nitrogen compounds play an important role in many processes that takes place in the natural waters. Nitrogen is also one of the basic compounds of protein, so it can enter surface water in sewage and industrial wastewater from the breakdown of proteins and other nitrogenous compounds. Nitrogen fertilizers are used extensively in agriculture and the excess over crop requirements is most leached into drainage water.

3.2.1.2.1- Ammonium content $\left(\mathrm{NH}_{3}\right)$ : The concentration of $\mathrm{NH}_{3}$ in El-Nasery canal and the oxidation ponds varies between $3.5-4.2$ and $15.4-63.0 \mathrm{mg} / \mathrm{l}$, respectively. While the groundwater samples at the study area contain $\mathrm{NH}_{3}$ lies between $2.8 \mathrm{mg} / 1$ (well No.10) and $6.3 \mathrm{mg} / 1$ (well No.11) with an average of $3.6 \mathrm{mg} / 1$. It noticed that both El-Nasery canal water samples and groundwater samples in the study area have $\mathrm{NH}_{3}$ concentrations more than the permissible limit $(0.5 \mathrm{mg} / \mathrm{l})$ due to the excess using of nitrogen fertilizers in the study area for the growing crops and seepage from the oxidation ponds. 
J. Environ. Sci.

Institute of Environmental Studies and Research - Ain Shams University

Table (3): The concentration of some trace elements (ppm) in the surface water and groundwater samples at the study area

\begin{tabular}{|c|c|c|c|c|c|c|c|c|c|c|c|c|c|}
\hline $\begin{array}{c}\text { Serial } \\
\text { No. }\end{array}$ & $\begin{array}{c}\text { Sample } \\
\text { No. }\end{array}$ & Al & $\mathrm{Cr}$ & $\mathbf{C u}$ & $\mathbf{F e}$ & Mn & $\mathbf{N i}$ & $\mathbf{P b}$ & $\mathbf{Z n}$ & B & Cd & Co & $\mathbf{B a}$ \\
\hline \multicolumn{14}{|c|}{ Surface water samples } \\
\hline \multicolumn{14}{|c|}{ EI - Nasery canal } \\
\hline 1 & 34 & 0.1385 & 0.0070 & 0.0152 & \begin{tabular}{|l|l|}
1.292 \\
\end{tabular} & 0.0765 & 0.0007 & 0.0028 & 0.0265 & ND & ND & 0.0011 & 0.0692 \\
\hline 2 & 36 & 0.1372 & 0.0079 & 0.0214 & 1.369 & 0.0856 & 0.0003 & 0.0029 & 0.0265 & ND & ND & 0.0012 & 0.0992 \\
\hline \multicolumn{14}{|c|}{$\begin{array}{l}\text { Drainage water samples (oxidation ponds) } \\
\end{array}$} \\
\hline 3 & 13 & 0.0761 & ND & 0.0081 & 0.1203 & 0.1411 & 0.0028 & 0.0030 & 0.0805 & 0.6660 & 0.0001 & 0.0022 & 0.1802 \\
\hline 4 & 14 & 0.3636 & 0.0063 & 0.0601 & 1.1360 & 0.2581 & 0.0282 & 0.0172 & 0.1145 & 0.1868 & 0.0022 & 0.0062 & 0.7027 \\
\hline \multicolumn{14}{|c|}{ Groundwater samples } \\
\hline 5 & 1 & ND & 0.0017 & 0.0212 & 0.0093 & 0.0014 & ND & 0.0063 & 0.4297 & ND & ND & 0.0008 & 0.0638 \\
\hline 6 & 2 & ND & 0.142 & 0.0071 & \begin{tabular}{|l|} 
ND \\
\end{tabular} & ND & ND & 0.0028 & 0.0020 & ND & ND & 0.0008 & 0.0476 \\
\hline 7 & 3 & ND & 0.0179 & 0.0104 & 0.0245 & ND & ND & 0.0025 & 0.0011 & 0.0438 & ND & 0.0006 & 0.0619 \\
\hline 8 & 4 & ND & 0.0036 & 0.2350 & 0.0398 & 0.0154 & ND & 0.0076 & 0.0042 & ND & ND & 0.0004 & 0.0844 \\
\hline 9 & 5 & ND & 0.0014 & 0.0069 & \begin{tabular}{|l|} 
ND \\
\end{tabular} & ND & ND & 0.0060 & 0.0651 & ND & ND & 0.0002 & 0.0864 \\
\hline 10 & 6 & ND & 0.0064 & 0.0326 & 0.1938 & ND & 0.0003 & 0.0050 & 0.1385 & ND & 0.0006 & ND & 0.0699 \\
\hline 11 & 7 & ND & 0.0140 & 0.0047 & 0.0011 & 0.0018 & ND & 0.0041 & 0.0054 & ND & ND & 0.0006 & 0.0081 \\
\hline 12 & 8 & 0.0574 & 0.0173 & 0.0010 & 0.3462 & 0.0035 & ND & 0.0004 & 0.0345 & ND & ND & 0.0013 & 0.0753 \\
\hline 13 & 9 & ND & 0.0107 & ND & ND & 0.0100 & $\mathrm{ND}$ & 0.0033 & \begin{tabular}{|l|} 
ND \\
\end{tabular} & ND & 0.0007 & 0.0004 & 0.0867 \\
\hline 14 & 10 & ND & 0.0011 & 0.028 & 0.2136 & 0.0298 & ND & 0.0024 & 0.0092 & ND & ND & 0.0005 & 0.0770 \\
\hline 15 & 11 & ND & 0.0127 & 0.0210 & 0.1990 & ND & 0.0001 & 0.0049 & 0.1806 & 0.1679 & 0.0023 & 0.0005 & 0.0739 \\
\hline 16 & 12 & ND & 0.0064 & 0.0130 & 0.0089 & ND & 0.0003 & 0.0040 & \begin{tabular}{|l|}
0.0049 \\
\end{tabular} & \begin{tabular}{|l|} 
ND \\
\end{tabular} & ND & 0.0005 & 0.0843 \\
\hline 17 & 15 & ND & 0.0124 & 0.0197 & 0.1408 & 0.0263 & 0.0169 & 0.0153 & 0.1200 & ND & 0.0007 & 0.0003 & 0.0842 \\
\hline 18 & 16 & 0.0376 & 0.0045 & 0.0085 & 0.4402 & 0.0416 & ND & 0.0041 & 0.2757 & ND & ND & 0.0017 & 0.0567 \\
\hline 19 & 17 & 0.0572 & 0.0054 & 0.0141 & 0.2609 & 0.0339 & ND & 0.0122 & 0.1601 & ND & 0.0001 & 0.0005 & 0.0705 \\
\hline 20 & 18 & 0.0267 & 0.0093 & 0.0057 & 0.1680 & 0.0578 & ND & 0.0074 & 0.0516 & ND & 0.0006 & 0.0006 & 0.0531 \\
\hline 21 & 19 & 0.0011 & ND & 0.0069 & 0.2009 & 0.0045 & ND & 0.0005 & 0.0666 & ND & 0.0012 & 0.0006 & 0.0568 \\
\hline 22 & 20 & 0.0522 & 0.0145 & 0.0045 & 0.1074 & 0.0034 & 0.0015 & 0.0005 & 0.0437 & ND & ND & 0.0005 & 0.0493 \\
\hline 23 & 21 & 0.1414 & 0.0087 & 0.0253 & 0.5299 & 0.1655 & ND & 0.0081 & 0.1364 & ND & 0.0001 & 0.0008 & 0.1041 \\
\hline 24 & 22 & ND & 0.011 & 0.0125 & 0.5007 & ND & 0.0336 & 0.0091 & 0.0444 & ND & \begin{tabular}{|l|} 
ND \\
\end{tabular} & 0.0005 & 0.1212 \\
\hline 25 & 23 & ND & 0.0092 & 0.0081 & 0.3252 & 0.1502 & ND & 0.0044 & 0.0581 & ND & 0.0002 & 0.0008 & 0.1263 \\
\hline 26 & 24 & ND & 0.0003 & 0.0225 & 0.2326 & 0.3086 & 0.006 & 0.0047 & 0.0460 & 0.1886 & 0.0002 & 0.0007 & 0.1373 \\
\hline 27 & 25 & 0.0685 & 0.0131 & 0.0057 & 0.7448 & 0.3578 & ND & 0.0030 & 0.0106 & \begin{tabular}{|l|} 
ND \\
\end{tabular} & ND & 0.0008 & 0.1049 \\
\hline 28 & 26 & 0.0230 & 0.0017 & ND & 0.3993 & 0.3606 & ND & 0.0048 & 0.0157 & ND & 0.0007 & 0.0011 & 0.0774 \\
\hline 29 & 27 & ND & 0.0001 & ND & 0.2065 & 0.4383 & ND & 0.0051 & \begin{tabular}{|l|}
0.1082 \\
\end{tabular} & \begin{tabular}{|l|} 
ND \\
\end{tabular} & ND & 0.0009 & 0.0997 \\
\hline 30 & 28 & ND & 0.0082 & 0.0153 & 0.0731 & ND & 0.0004 & 0.0042 & 0.0042 & 0.1454 & ND & 0.0003 & 0.0116 \\
\hline 31 & 29 & ND & 0.0050 & 0.0115 & 0.3142 & 0.3050 & ND & 0.0044 & 0.0187 & \begin{tabular}{|l|} 
ND \\
\end{tabular} & 0.0001 & 0.0005 & 0.0745 \\
\hline
\end{tabular}


Cont. table (3): The concentration of some trace elements (ppm) in the surface water and groundwater samples at the study area

\begin{tabular}{|c|c|c|c|c|c|c|c|c|c|c|c|c|c||}
\hline $\begin{array}{c}\text { Serial } \\
\text { No. }\end{array}$ & $\begin{array}{c}\text { Sample } \\
\text { No. }\end{array}$ & Al & $\mathbf{C r}$ & $\mathbf{C u}$ & $\mathbf{F e}$ & $\mathbf{M n}$ & $\mathbf{N i}$ & $\mathbf{P b}$ & $\mathbf{Z n}$ & $\mathbf{B}$ & $\mathbf{C d}$ & $\mathbf{C o}$ & Ba \\
\hline \hline \multicolumn{10}{|c|}{ Groundwater samples } \\
\hline 32 & 30 & ND & 0.0100 & 0.0377 & 0.3555 & 0.2469 & ND & 0.0063 & 0.0279 & ND & 0.0003 & 0.0003 & 0.744 \\
\hline 33 & 31 & ND & 0.0066 & 0.0139 & 0.1620 & 0.0786 & ND & 0.0045 & 0.0002 & ND & ND & 0.0006 & 0.0523 \\
\hline 34 & 32 & ND & ND & 0.0040 & 3.286 & 0.5483 & 0.0007 & 0.0026 & ND & ND & ND & 0.0013 & 0.0800 \\
\hline 35 & 33 & ND & 0.0018 & 0.0066 & 0.1200 & 0.1267 & ND & 0.0042 & ND & ND & ND & 0.0003 & 0.0693 \\
\hline 36 & 35 & 0.1245 & 0.0014 & 0.0079 & 0.2957 & 0.0743 & 0.0005 & 0.0004 & 0.0161 & ND & ND & 0.0017 & ND \\
\hline 37 & 37 & ND & 0.006 & 0.216 & ND & ND & ND & 0.0003 & ND & ND & ND & 0.0010 & ND \\
\hline 38 & 38 & ND & 0.0065 & 0.0288 & 1.376 & 0.6219 & ND & 0.0012 & ND & ND & ND & 0.0007 & ND \\
\hline 39 & 39 & ND & 0.0066 & 0.0062 & 1.046 & 0.3980 & ND & 0.0033 & ND & ND & ND & 0.0005 & ND \\
\hline 40 & 40 & ND & 0.0055 & 0.0129 & 1.258 & 0.3820 & ND & 0.0013 & 0.0013 & ND & ND & 0.0006 & ND \\
\hline 41 & 41 & ND & 0.0030 & 0.0239 & 0.5386 & 0.3243 & ND & 0.0039 & 0.0017 & ND & ND & 0.0008 & ND \\
\hline 42 & 42 & ND & 0.0078 & 0.0283 & 1.722 & 0.7008 & ND & 0.0049 & 0.0004 & ND & ND & 0.0011 & ND \\
\hline 43 & 43 & ND & ND & 0.040 & 1.927 & 0.6573 & ND & 0.0028 & 0.0056 & ND & ND & 0.0009 & ND \\
\hline 44 & 44 & 0.0465 & 0.0101 & 0.132 & 1.857 & 0.8213 & ND & 0.0047 & 0.0111 & ND & ND & 0.0009 & ND \\
\hline 45 & 45 & ND & 0.0106 & 0.0315 & 0.2827 & 0.2118 & ND & 0.0086 & 0.0516 & ND & ND & 0.0004 & ND \\
\hline Permissible & 0.2 & 0.05 & 1.5 & 0.3 & 0.4 & 0.07 & 0.01 & 0.05 & 1.00 & 0.003 & 0.05 & 0.7 \\
\hline
\end{tabular}

3.2.1.2.2- Nitrite content $\left(\mathrm{NO}_{2}^{-}\right)$: Nitrite (NO2-) content in El-Nasery canal and the oxidation pond water samples ranges from $0.02-0.08$ and $7.65-$ $15.1 \mathrm{mg} / \mathrm{l}$, respectively. The concentration of groundwater samples at the study area ranges from $0.02 \mathrm{mg} / \mathrm{l}$ (well No.21) to $4.08 \mathrm{mg} / \mathrm{l}$ (well No.12) with an average of $0.88 \mathrm{mg} / \mathrm{l}$. The data in Table (4) indicated that most of the groundwater samples $(60 \%)$ in the study area have NO2-content more the acceptable limit $(0.2 \mathrm{mg} / \mathrm{l})$, this is may be due to the agriculture activity and the seepage from the drainage water (oxidation ponds) which show a higher concentration of nitrite. 
J. Environ. Sci.

Institute of Environmental Studies and Research - Ain Shams University

Table (4): Concentration of nitrogen forms and phosphate compounds (mg/l) in the surface water and groundwater samples at the study area

\begin{tabular}{|c|c|c|c|c|c|c|}
\hline Serial No. & Sample No. & $\mathbf{N H}_{3}$ & $\mathrm{NO}_{2}^{-}$ & $\mathrm{NO}_{3}^{-}$ & Total N & $\mathrm{PO}_{4}{ }^{3-}$ \\
\hline \multicolumn{7}{|c|}{ Surface water samples } \\
\hline \multicolumn{7}{|c|}{ El-Nasery canal } \\
\hline 1 & 34 & 4.2 & 0.02 & 1.84 & 6.06 & 0.11 \\
\hline 2 & 36 & 3.5 & 0.08 & 1.75 & 5.33 & 0.14 \\
\hline \multicolumn{7}{|c|}{ Drainage water samples ( Oxidation ponds ) } \\
\hline 3 & 13 & 15.4 & 15.10 & 16.85 & 47.35 & 1.78 \\
\hline 4 & 14 & 63 & 7.65 & 11.20 & 81.85 & 2.16 \\
\hline \multicolumn{7}{|c|}{ Groundwater samples } \\
\hline 5 & 1 & 3.5 & 0.15 & 3.03 & 6.68 & 0.16 \\
\hline 6 & 2 & 4.2 & 2.89 & 14.50 & 21.59 & 0.15 \\
\hline 7 & 3 & 4.2 & 0.75 & 20.88 & 25.83 & 0.15 \\
\hline 8 & 4 & 2.8 & 0.21 & 0.49 & 3.50 & 0.13 \\
\hline 9 & 5 & 4.2 & 0.29 & 0.58 & 5.07 & 0.13 \\
\hline 10 & 6 & 2.8 & 0.46 & 12.84 & 16.10 & 0.15 \\
\hline 11 & 7 & 6.3 & 3.31 & 8.25 & 17.86 & 0.86 \\
\hline 12 & 8 & 4.2 & 4.08 & 22.84 & 31.12 & 0.11 \\
\hline 13 & 9 & 3.5 & 0.38 & 0.41 & 4.29 & 0.10 \\
\hline 14 & 10 & 4.9 & 0.17 & 0.24 & 5.31 & 0.11 \\
\hline 15 & 11 & 3.5 & 3.70 & 37.80 & 44.70 & 0.24 \\
\hline 16 & 12 & 2.8 & 2.58 & 7.88 & 13.26 & 0.58 \\
\hline 17 & 15 & 2.8 & 0.21 & 0.57 & 3.58 & 0.13 \\
\hline 18 & 16 & 4.2 & 0.48 & 0.29 & 4.97 & 0.13 \\
\hline 19 & 17 & 4.2 & 0.07 & 0.78 & 5.05 & 0.75 \\
\hline 20 & 18 & 28 & 016 & 129 & 425 & 032 \\
\hline 21 & 19 & 28 & 002 & 194 & 476 & 011 \\
\hline 22 & 20 & 4.2 & 0.22 & 11.07 & 15.49 & 0.17 \\
\hline 23 & 21 & 28 & 125 & 523 & 928 & 0.13 \\
\hline 24 & 22 & 2.8 & 0.28 & 4.26 & 7.34 & 0.11 \\
\hline
\end{tabular}


Cont. table (4): Concentration of nitrogen forms and phosphate compounds $(\mathrm{mg} / \mathrm{l})$ in the surface water and groundwater samples at the study area

\begin{tabular}{|c|c|c|c|c|c|c|}
\hline $\begin{array}{l}\text { Serial } \\
\text { No. }\end{array}$ & $\begin{array}{c}\text { Sample } \\
\text { No. }\end{array}$ & $\mathbf{N H}_{3}$ & $\mathrm{NO}_{2}^{-}$ & $\mathrm{NO}_{3}^{-}$ & Total N & $\mathrm{PO}_{4}{ }^{3-}$ \\
\hline \multicolumn{7}{|c|}{ Groundwater samples } \\
\hline 25 & 23 & 3.5 & 0.45 & 0.21 & 4.16 & 0.13 \\
\hline 26 & 24 & 3.5 & 2.55 & 32.22 & 38.27 & 0.11 \\
\hline 27 & 25 & 2.8 & 1.32 & 0.14 & 4.26 & 0.10 \\
\hline 28 & 26 & 4.2 & 0.49 & 0.14 & 4.83 & 0.10 \\
\hline 29 & 27 & 2.8 & 1.22 & 0.09 & 4.11 & 0.10 \\
\hline 30 & 28 & 2.8 & 0.81 & 48.50 & 52.11 & 0.11 \\
\hline 31 & 29 & 3.5 & 1.10 & 0.03 & 4.63 & 0.11 \\
\hline 32 & 30 & 3.5 & 0.40 & 0.12 & 4.02 & 0.11 \\
\hline 33 & 31 & 4.2 & 0.06 & 0.03 & 4.29 & 0.10 \\
\hline 34 & 32 & 3.5 & 0.79 & 19.70 & 23.99 & 0.11 \\
\hline 35 & 33 & 3.5 & 0.17 & 0.09 & 3.76 & 0.11 \\
\hline 36 & 35 & 4.2 & 0.06 & 1.41 & 5.67 & 1.55 \\
\hline 37 & 37 & 3.5 & 0.23 & 22.92 & 26.65 & 0.19 \\
\hline 38 & 38 & 6.3 & 0.09 & 0.05 & 6.44 & 0.15 \\
\hline 39 & 39 & 4.2 & 0.39 & 1.85 & 6.44 & 0.11 \\
\hline 40 & 40 & 3.5 & 0.26 & 5.46 & 9.22 & 0.11 \\
\hline 41 & 41 & 4.2 & 0.18 & 0.60 & 4.98 & 0.15 \\
\hline 42 & 42 & 3.5 & 0.56 & 0.21 & 4.27 & 8.42 \\
\hline 43 & 43 & 3.5 & 0.86 & 0.68 & 5.04 & 0.88 \\
\hline 44 & 44 & 4.2 & 1.10 & 0.05 & 5.35 & 0.94 \\
\hline 45 & 45 & 2.8 & 1.00 & 0.12 & 3.92 & 0.38 \\
\hline \multicolumn{2}{|c|}{ Permissible Limit } & 0.50 & 0.2 & 45 & 50 & 1 \\
\hline
\end{tabular}

3.2.1.2.3 - Nitrate content $\left(\mathrm{NO}_{3}{ }^{-}\right)$: Noteworthy to mention that the $\mathrm{NO}_{3}{ }^{-}$is considered the final stage of $\mathrm{NH}_{4}^{+}$oxidation passing with $\mathrm{NO}_{2}^{-}$in the presence of bacteria and oxygen. 
J. Environ. Sci.

Institute of Environmental Studies and Research - Ain Shams University

\section{Microbial}

\section{Nitrate $\left(\mathrm{NO}_{3}{ }^{-}\right) \longrightarrow$ Nitrite $\left(\mathrm{NO}_{2}{ }^{-}\right)$ \\ Reduction}

The primary source of nitrates in the groundwater is the leaching of $\mathrm{NO}_{3}{ }^{-}$ salts into the groundwater supply from fertilizers and the seepage of sewage water. Liu et al. (2005) stated that agricultural practices result in non-point source pollution of groundwater and the effect of these practices accumulate confirm over time. Point sources of $\mathrm{N}$ such as septic system contribute to nitrate pollution of groundwater.

The concentration of nitrate in El-Nasery canal and the oxidation water samples varies between $1.75-1.84$ and $11.20-16.85 \mathrm{mg} / \mathrm{l}$, respectively. The concentration of nitrate in the groundwater samples at the study area ranges from $0.03 \mathrm{mg} / \mathrm{l}$ (well No.31) to $48.50 \mathrm{mg} / \mathrm{l}$ (well No.30) with an average of $3.90 \mathrm{mg} / \mathrm{l}$. It is important to mention that El-Nasery canal and the groundwater samples, except one sample (No.30) that have nitrate concentrations less than the permissible limit $(45 \mathrm{mg} / \mathrm{l})$. This is due to the instability of the nitrate and its reduction to nitrite.

3.2.1.2.4- Total nitrogen content: Total nitrogen calculated by the summation of all nitrogen forms $\left(\mathrm{NH}_{4}{ }^{+}, \mathrm{NO}_{2}{ }^{-}\right.$and $\left.\mathrm{NO}_{3}{ }^{-}\right)$. The total $\mathrm{N}$ concentrations for El-Nasery canal and the oxidation ponds samples varies between $5.33-6.06$ and $1.20-16.85 \mathrm{mg} / \mathrm{l}$, respectively. The groundwater samples at the study area have total nitrogen ranges from $3.50 \mathrm{mg} / \mathrm{l}$ (well No.8) to $52.11 \mathrm{mg} / \mathrm{l}$ (well No.30) with an average of $11.39 \mathrm{mg} / 1$. 
In general, the presence of high ammonium concentration in some water samples more than the nitrate concentration, confirms that the concerned water subjected to reducing conditions more than oxidizing ones. On the contrary, $\mathrm{NO}_{3}{ }^{-}$concentration exceeds $\mathrm{NH}_{4}{ }^{+}$in the rest of the samples confirms the prevalence oxidizing condition.

3.2.1.3-Phosphate content $\left(\mathrm{PO}_{4}^{3-}{ }^{3-}\right)$ : Phosphate concentrations in El-Nasery canal and the oxidation ponds water samples was found to be in the range from $0.11-0.14$ and $1.78-2.16 \mathrm{mg} / \mathrm{l}$, respectively. On the other hand, the concentration of Phosphate in the groundwater samples at the study area as shown in ranges from $0.10 \mathrm{mg} / \mathrm{l}$ (well No.13) - 8.42mg/l (wellNo.42) with an average of $0.12 \mathrm{mg} / \mathrm{l}$. In conclusion all the water samples in the study area lie within the acceptable limit according to WHO (1996) because all of them have concentrations less than $1 \mathrm{mg} / \mathrm{l}$, with exception of two groundwater samples (35 and 42). The lowest concentration of phosphate is due to soil capability of adsorption for phosphate ions.

3.2.2-Biological pollutants: The biological pollutants in the surface water and groundwater samples at the study area was discussed through the determination of total organic carbon (TOC), biological oxygen demand (BOD) and chemical oxygen demand (COD) as in table (5).

3.2.2.1- Total Organic Carbon (TOC): The obtained values of the TOC were in the range from $8.2-8.6 \mathrm{mg} / \mathrm{l}$ and 111 to $146 \mathrm{mg} / \mathrm{l}$ for El-Nasery canal and the oxidation ponds water samples, respectively. On the other hand, the groundwater samples have TOC concentration ranges from 4.1 to $8.2 \mathrm{mg} / \mathrm{l}$ with an average of $5.8 \mathrm{mg} / \mathrm{l}$. The results of TOC reveal that both of El-Nasery 
canal water samples and $44 \%$ of the selected groundwater samples at the study area are fairly polluted as they have concentrations to some extent close to the contamination limit $(10 \mathrm{mg} / \mathrm{l})$, this is due to the seepage from the oxidation ponds that have higher values than the permissible limit, which reveal the pollution of it.

3.2.2.2 - Biological Oxygen Demands (BOD): El-Nasery canal water sample have not biological oxygen demands contents. The oxidation water samples are polluted as they have BOD values ranging from $111-137 \mathrm{mg} / \mathrm{l}$, while the selected groundwater samples in the study area have BOD values range from 0 to $6.4 \mathrm{mg} / \mathrm{l}$, with a mean value of $1.37 \mathrm{mg} / \mathrm{l}$. These data mean that the oxidation ponds act as a reduction agent for the pollution of human activity. The majority of the selected groundwater samples in the study area have BOD values less than the contamination limit except one sample, which indicates the human activity at El-Sadat city and the effect of the oxidation ponds. The appearance of some contaminated groundwater samples confirms the occurrence of pathogenic microorganisms belong to the family interbacteriaceae in such water samples. 
Table (5): The biological measurements for some selected water samples in the study area expressed as $\mathrm{mg} / \mathrm{l}$

\begin{tabular}{|c|c|c|c|c|}
\hline Serial No. & Sample No. & TOC & BOD & COD \\
\hline \multicolumn{5}{|c|}{ Surface water samples } \\
\hline \multicolumn{5}{|c|}{ El-Nasery canal } \\
\hline 1 & 34 & 8.2 & 0 & 32.1 \\
\hline 2 & 36 & 8.6 & 0 & 33.4 \\
\hline \multicolumn{5}{|c|}{ Drainage water samples (Oxidation ponds ) } \\
\hline 3 & 13 & 111 & 137 & 102.3 \\
\hline 4. & 14 & 146 & 111 & 88.8 \\
\hline \multicolumn{5}{|c|}{ Some selected groundwater samples } \\
\hline 5 & 1 (Well 1) & 4.1 & 0 & 15.3 \\
\hline 6 & 2 (Well 2) & 4.8 & 2.9 & 19.3 \\
\hline 7 & 3 (Well 3) & 5.6 & 3.4 & 31.3 \\
\hline 8 & 4 (Well 4) & 8.2 & 0 & 16.2 \\
\hline 9 & 5 (Well 5) & 4.7 & 0 & 36.4 \\
\hline 10 & $8($ Well 8) & 6.3 & 2.6 & 41.3 \\
\hline 11 & $11($ Well 11) & 7.2 & 0 & 40.1 \\
\hline 12 & 12 (Well 12) & 6.1 & 0 & 18.1 \\
\hline 13 & 16 (Well 14) & 8.0 & 2.3 & 15.1 \\
\hline 14 & 23 (Well 21) & 4.4 & 1.9 & 13.8 \\
\hline 15 & 24 (Well 22) & 4.9 & 0 & 15.9 \\
\hline 16 & 25 (Well 23) & 5.3 & 0 & 18.4 \\
\hline 17 & 29 (Well 27) & 5.7 & 2.4 & 19.3 \\
\hline 18 & 34 (Well 32) & 6.2 & 6.4 & 21.6 \\
\hline 19 & 40 (Well 40) & 5.3 & 0 & 19.3 \\
\hline 20 & 42 (Well 42) & 6.2 & 0 & 22.4 \\
\hline \multicolumn{2}{|c|}{ Permissible Limit } & 10 & 6 & 10 \\
\hline
\end{tabular}

3.2.2.3 - Chemical Oxygen Demands: The obtained results of COD obviously do not correspond to the values of BOD, where COD values are higher than the BOD values. This is useful where it may helpful in comparing conditions in stream at one time to another time. The COD values range 32.1 to $33.4 \mathrm{mg} / \mathrm{l}$ and $88.8-102.3 \mathrm{mg} / \mathrm{l}$ for El-Nasery canal and oxidation ponds 
water samples, respectively. The selected groundwater samples at the study area have COD contents range from 13.8 to $41.3 \mathrm{mg} / \mathrm{l}$ with a mean value of $22.74 \mathrm{mg} / 1$, it noticed that the values of COD contents in all surface and groundwater water samples (El Nasery canal and groundwater samples) are higher than the permissible limit due to the direct effect of seepage of drainage water (Oxidation ponds) to the groundwater samples.

3.2.3- Microbial pollutants: This part of pollution will be discussed based on the microbial analysis of selected water samples at the study area (20 water samples;2 surface water samples from El-Nasery canal, 2 water samples from the oxidation ponds and 16 groundwater samples) as shown in table (6).

The obtained data indicate that the total viable counts $\left(\mathrm{TVC}_{\mathrm{S}}\right)$ vary between $19 \times 10^{2}$ to $21 \times 10^{2} \mathrm{cfu} / \mathrm{ml}$ for El-Nasery canal, $220 \times 10^{2}$ to 360 $\mathrm{x} 10^{2} \mathrm{cfu} / \mathrm{ml}$ for the oxidation ponds and $10.2 \times 10^{2}$ to $45.0 \times 10^{2} \mathrm{cfu} / \mathrm{ml}$ for groundwater samples. The total Coliforms (MPN) range from 1100 - 1300 $\mathrm{cfu} / 100 \mathrm{ml}$ for the oxidation ponds and 0-20 cfu/100 $\mathrm{ml}$ groundwater samples, while being nil for El-Nasery canal. The faecal coliforms of the study water samples range from $32-38 \mathrm{cfu} / 100 \mathrm{ml}$ for the oxidation ponds and 0-5 cfu/100 $\mathrm{ml}$ for groundwater samples, while being nil for El-Nasery canal. It is important to mention that the recommended of the total coliforms standard value for wastewater is $\left(1 \times 10^{2} \mathrm{cfu} / \mathrm{ml}\right)$, while being nil for natural water, FAO (1997) and Okonko et al., (2008). These data agreed with El Sayed et al., (2012) who observed high total colony counts of the wastewater of the studied areas. There were four groundwater samples have total and faecal bacteria ( E. coli), which are unsutable for drinking human, livestock and poultry. However, the water from the oxidation ponds have both of $\mathrm{E}$. 
coliand and Salmonella typhi, indicating the unsuitability of using this type of water for drinking or irrigation the economic crops either eaten uncooked or cooked, while it may be used to irrigate the wood trees as happened at ElSadat city.

According to WHO (2011), the recommended limits for irrigation vegetables likely to be eaten uncooked was $200 \mathrm{MPN} / 100 \mathrm{ml}$ and irrigation the ornamental fruit trees and fodder crops was 1000 MPN/ $100 \mathrm{ml}$.

Therefore, all groundwater samples (except the mentioned four samples) and the surface water samples from El-Nasery canal are suitable for drinking, industrial and agricultural purposes. However, the four groundwater samples were not suitable for irrigation the vegetables especially which eaten uncooked.

Finally; it can be concluded that this study proved that the quality of groundwater in the study area affected by the seepage from oxidation ponds. This is confirmed by the previous study as Khurana and Pritpal (2012) that revealed that the chemical composition of groundwater varies remarkably with their heavy metal content, $\mathrm{pH}, \mathrm{EC}$, biochemical oxygen demand (BOD), chemical oxygen demand (COD) and alkalinity and hardness. 
J. Environ. Sci.

Institute of Environmental Studies and Research - Ain Shams University

Table (6): The total viable bacteria counts (TVBC) x $102 \mathrm{cfu} / \mathrm{ml}$, the most probable number (MPN) of total coliforms (TC), fecal coliforms (FC)/ 100ml and triple sugar iron for the selected water samples at the study area

\begin{tabular}{|c|c|c|c|c|c|}
\hline $\begin{array}{c}\text { Serial } \\
\text { No. }\end{array}$ & $\begin{array}{c}\text { Sample } \\
\text { No. }\end{array}$ & $\begin{array}{c}\text { Total } \\
\text { Coliforms } \\
\text { MPN/100 ml }\end{array}$ & $\begin{array}{c}\text { Fecal } \\
\text { Coliforms } \\
\text { cfu } / 100 \text { ml }\end{array}$ & $\begin{array}{c}\text { Total microbes } \\
\text { counts (TVC) } \\
\text { x } 10^{2} \\
\text { cfu } / \mathrm{ml}\end{array}$ & $\begin{array}{c}\text { TSI } \\
\text { Triple Sugar } \\
\text { Iron }\end{array}$ \\
\hline \multicolumn{6}{|c|}{ Surface water samples } \\
\hline \multicolumn{6}{|c|}{ El-Nasery canal samples } \\
\hline 1 & 34 & 19.0 & - & - & - \\
\hline 2 & 36 & 21.0 & - & - & - \\
\hline \multicolumn{6}{|c|}{ Drainage water samples ( Oxidation ponds ) } \\
\hline 3 & 13 & 220 & 1100 & 38 & $\begin{array}{c}\text { E. Coli }+ \\
\text { Salmonella typhi }\end{array}$ \\
\hline 4 & 14 & 360 & 1300 & 32 & $\begin{array}{c}\text { E. Coli }+ \\
\text { Salmonella typhi }\end{array}$ \\
\hline \multicolumn{6}{|c|}{ Groundwater samples } \\
\hline 5 & $1($ Well 1) & 10.2 & - & - & - \\
\hline 6 & 2 (Well 2) & 12.1 & - & - & - \\
\hline 7 & 3 (Well 3) & 19.4 & - & - & - \\
\hline 8 & 4 (Well 4) & 26.5 & - & - & - \\
\hline 9 & 5 (Well 5) & 12.1 & - & - & - \\
\hline 10 & 8 (Well 8) & 20.2 & - & - & - \\
\hline 11 & 11 (Well 11) & 38.0 & 20 & 5 & E. Coli \\
\hline 12 & \begin{tabular}{|l|}
12 (Well 12) \\
\end{tabular} & 45.0 & 20 & 4 & E. Coli \\
\hline 13 & 16 (Well 14) & 12.4 & - & - & - \\
\hline 14 & 23 (Well 21) & 19.5 & - & - & - \\
\hline 15 & 24 (Well 22) & 11.6 & - & - & - \\
\hline 16 & 25 (Well 23) & 0.31 & - & - & - \\
\hline 17 & 29 (Well 27) & 29.0 & 15 & 3 & E. Coli \\
\hline 18 & 34 (Well 32) & 25.3 & 15 & 5 & E. Coli \\
\hline 19 & 40 (Well 40) & 18.4 & - & - & - \\
\hline 20 & 42 (Well 42) & 13.2 & - & - & - \\
\hline \multicolumn{2}{|c|}{ Permissible Limit } & $100 / \mathrm{ml}$ & $20 / 100 \mathrm{ml}$ & 0 & \\
\hline
\end{tabular}

3.3- Water Evaluation: Water quality evaluation for different purposes such as human drinking, laundry, agricultural and industrial was evaluated 
according to international standards, Egyptian higher committee for water (2007) and WHO (2011).

\subsection{1 - Evaluation of the water quality for human drinking: Comparing} the obtained data (table 1) and the international standards as mentioned in the table (7), can be concluded that;

According to the salinity, the surface water samples in the study area (ElNasery canal) is suitable for drinking as they have salinity vary from 296 to $303 \mathrm{mg} / \mathrm{l}$, i.e., less than the permissible limit $(1200 \mathrm{mg} / \mathrm{l})$. On the other hand, the majority of the groundwater samples (90\%) in the study area are suitable for human drinking, as they have salinity less than $1200 \mathrm{mg} / \mathrm{l}$, while the rest of the groundwater samples (10\%) in the study area are unsuitable for human drinking as they have salinity more than $1200 \mathrm{mg} / 1$.

By comparing the maximum permissible limits of heavy and trace constituents $(\mathrm{Fe}, \mathrm{Pb}, \mathrm{Cr}, \mathrm{Cu}, \mathrm{Co}, \mathrm{Cd}$ and $\mathrm{Zn})$ as shown in table (7) for drinking water with the obtained data (table 3), it is found that El-Nasery canal water are unsuitable for drinking as they have Fe concentrations more than the permissible limit at these locations. On the other hand, $61 \%$ of the groundwater samples in the study area are suitable for drinking as they have concentrations of heavy and trace constituents less than the permissible limit of contamination, while the rest of the samples (39\%) are unsuitable for drinking as they have $\mathrm{Cr}, \mathrm{Fe}, \mathrm{Mn}$ and $\mathrm{Zn}$ concentrations higher than the permissible limits. 
J. Environ. Sci.

Institute of Environmental Studies and Research - Ain Shams University

Table (7): Water quality guidelines for human drinking and domestic uses.

(According to the international standards)

\begin{tabular}{|c|c|c|c|c|}
\hline $\begin{array}{l}\text { Chemical constituent } \\
\text { or parameter }\end{array}$ & $\begin{array}{c}\text { Eurppean }^{1} \\
\text { Standar'ds mg/l }^{\prime}\end{array}$ & $\begin{array}{l}\text { International }^{2} \\
\text { Standards mg/l }\end{array}$ & \begin{tabular}{|c|}
$\begin{array}{c}\text { Egyptian }^{3} \\
\text { maximum } \\
\text { limits in } \mathrm{mg} / \mathrm{l}\end{array}$ \\
\end{tabular} & $\begin{array}{c}\text { World }{ }^{4} \text { Health } \\
\text { Organization } \\
\text { guidelines mg/l }\end{array}$ \\
\hline Aluminum & 0.05 to 0.2 & - & 0.2 & 0.2 \\
\hline Arsenic & $<0.05$ & $<0.05$ & 0.0 & - \\
\hline Barium & $<1.00$ & $<1.0$ & 1.0 & - \\
\hline Boron ${ }^{*}$ & 1.00 & - & - & - \\
\hline Cadmium & $<0.01$ & $<0.01$ & 0.005 & - \\
\hline Calcium & $75-200$ & $75-200$ & 200 & - \\
\hline Chloride & - & - & 500 & 250 \\
\hline Copper & $<0.05$ & $0.05-1.5$ & 1.00 & 1.00 \\
\hline Cyanides & $>0.05$ & $<0.05$ & 0.05 & - \\
\hline Fluoride & - & $1.4-2.4$ & 0.8 & - \\
\hline Hardness as $\mathrm{CaCO}_{3}$ & $2-10 \mathrm{me} / \mathrm{l}$ & $2-100 \mathrm{me} / \mathrm{l}$ & $500 \mathrm{mg} / \mathrm{l}$ & - \\
\hline Iron ( total) & $<0.1$ & $0.1-1.0$ & $0.3-1.0$ & 0.3 \\
\hline $\begin{array}{c}\text { Magnesium } \\
\text { If } \mathrm{SO}_{4}>250 \mathrm{mg} / 1 \\
\text { If } \mathrm{SO}_{4}<250 \mathrm{mg} / 1\end{array}$ & $\begin{array}{l}<30 \\
<125 \\
\end{array}$ & $\begin{array}{l}<30 \\
<125 \\
\end{array}$ & 150 & - \\
\hline Manganese & $<0.01$ & $0.1-0.5$ & 0.001 & 0.1 \\
\hline Mercury (total) & $<0.01$ & $<0.01$ & 0.001 & - \\
\hline $\begin{array}{c}\text { Nitrate as } \mathrm{N} \\
\text { recommendation } \\
\text { Acceptable } \\
\text { Not recommended }\end{array}$ & $\begin{array}{l}<50 \text { for bodies } \\
\text { less than three } \\
\text { months } \\
50-100 \text { for } \\
\text { Older children } \\
\text { and adults } \\
>100\end{array}$ & - & 10 & - \\
\hline TDS & - & $500-1500$ & 1200 & 1000 \\
\hline $\mathrm{pH}$ & $7-8.5$ & - & $6.5-9.2$ & - \\
\hline Sodium & - & - & 200 & 200 \\
\hline Sulfates & $<250$ & $250-400$ & 400 & 250 \\
\hline Zinc & $<5$ & $5-15$ & 5 & 3 \\
\hline Lead & $<0.1$ & $<0.1$ & 0.05 & - \\
\hline
\end{tabular}


1- World Health Organization (1971). European standards for drinking water, secon edition, Geneva, WHO.

2- World Health Organization (1972). International standards for drinking water, 3rd edition, Geneva, WHO.

3- Egyptian standards for drinking and domestic uses (Higher Committee for water, 2007).

4- World Health Organization (2011). Guidelines of drinking water quality. Incorporating First Addendum 4th edition, Geneva, WHO.

\section{CONCOLUSION}

1 - The chemical fertilizers and pesticides should be used at minimum limits as they considered a part of water pollution at El-Sadat city.

2 - Industrial wastewater should be treated at the industry's site before being delivered in the oxidation ponds, where it may be recycled at the plant.

3 - The groundwater in the study area must be treated before using.

4- Carrying out periodical chemical, biological and microbial analysis for the water resources in the study area to follow up the changes of these sources especially in groundwater nearer to the oxidation ponds.

\section{REFERENCE}

American Public Health Association, (APHA), (1989): Standards Methods for the Examination of Water and Wastewater. 17thedition, New York, U.S.A.

Chebotarev, I.I., (1955): Metamorphism of natural waters in the crust of weathering. Geochemia et.Cosmochimica, Acta, 8, part I. pp.2248, part II. pp.137-170 and part III. pp.198-212, Londonand New York. 
El- Sayed, M.M; El Aassar, A.M.; Abo El - Fadi, M.M and Abd El - Gawad, A.M. (2012): Hydro- geochemistry and pollution problems in 10th of Ramadan city, east El - Delta, Egypt. J. Appl. Sci. Res., 8, 4, $1959-1972$.

El - Tahawy, M.; Nassef, M.; Gamal, Y.andZaki, L. (2006): Radiological of natural and man -made radioactivity in two new industrial Egyptian cities. VIII Radiation Physics \& Protection Conference, Assessment of industrial contamination of agricultural soil adjacent to El- Sadat city, Egypt.

Egyptian Higher Committee for water (1997): Egyptian standads for drinking water and domestic uses. Egypt (in Arabic).

Fishman, A.E and Friedman, L.G., (1985): Methods for determination of inorganic substance in water and fluvial sediments. U.S. Geo,Sur., Book 5, Chapter A1. Open File Report, pp. 485 - 495, Denver, Colorado, U.S.A.

Food and Agriculture Organization , FAO (1997): Chemical analysis manual for food and water. 5th Ed., Roma, Italy, 1, $20-26$.

Higher Committee for water (2007): Egyptian standards for drinking water and domestic uses. Cairo, Egypt (In Arabic).

Khurana, M.P.S.andPritpal, S. (2012): Wastewater use in crop production: A Review. Resources and Environment, 2, 4, 116 -131.

Okonko, I.O.; Adejoye, O.D.; Ogunnusi, T.A.; Fajobi, E.A. and Shittu, O.B., (2008): Microbiological and physicochemical analysis of different water samples used for domestic purposes in Abeokuta and Ojota. Lagos State, Nigeria. Afr. J. Biotechnol., 7 (3): 617621.

Rainwater, F.H. and L.L. Thatcher, (1960):. Methods for collection and analysis of water samples. U.S.

Wael Badway; ClesyaYa. Chepurchenko; Hussein El- Salman and Mariana V. Frontasyeva (2016): Assessment of industrial contamination of agricultural soil adjacent to Sadat city, Egypt. Chem. Eng., 23, 2, 297-310. 
World Health Organization (1996): Guidelines for drinking water quality. Geneva, 2nd edition, Vol. 2, Health Criteria and other supporting information.

World Health Organization, (2011): Guideline of drinking water quality, Incorporating First Addendum. 4th ed., Geneva: World Health Organization.

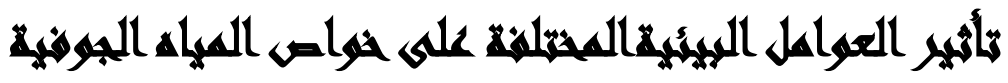

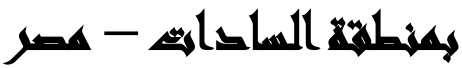

[1]

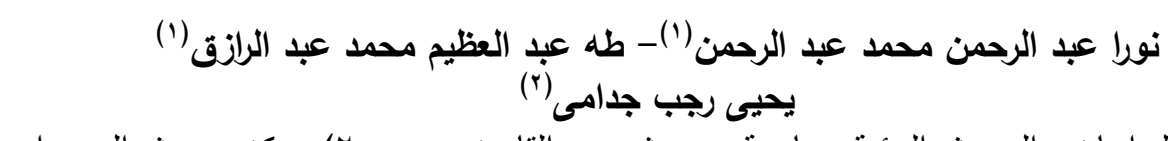
(1) معهد الدراسات والبحوث البيئية، جامعة عين شمس، القاهرة، مصر ب) مركز بحوث الصحراء، القاهرة، مصر الإن

\section{المستصنص:}

تهدف هذه الدراسة إلى تقييم الوضع الهيدروكيميائى ومدى التلوث الكيميائي والميكروبى للمياه

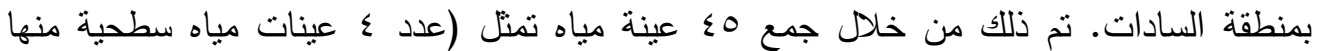

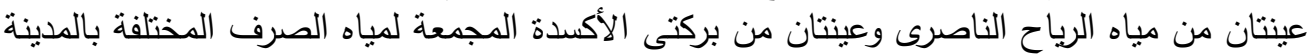

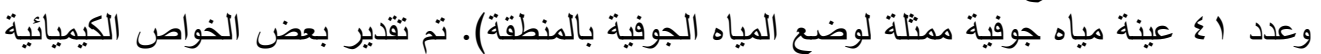

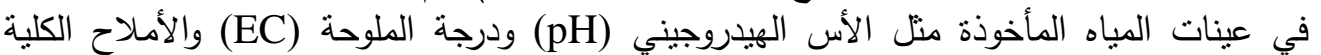
الذائبة (TDS) وكذلك تم تقدير بعض العناصر النادرة والمعادن التقيلة علاوة على تقدير الكانيونات

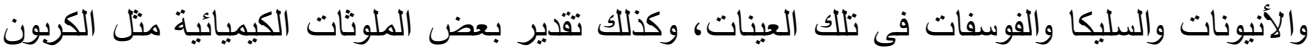

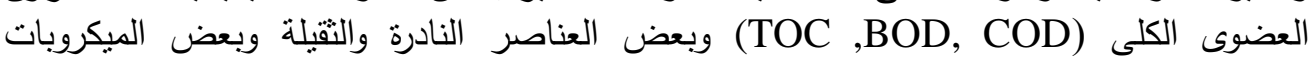
المرضة مثل Salmonella typhi ،E. coli.

أظهرت النتائج أن نوعية المياه المتواجدة في منطقة الدراسة تتمثل في نوعين من المياه هما

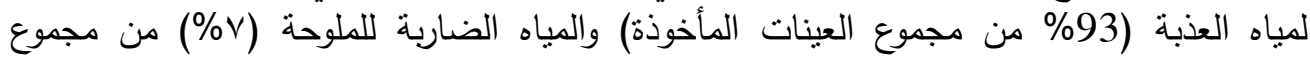

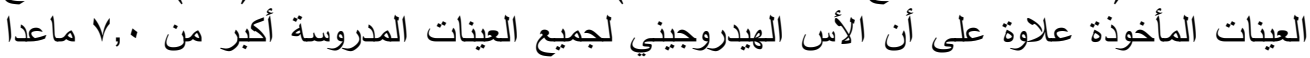
عينتان. أيضا أظهرت النتائج خلو مياه الرياح الناصرى ومعظم الإنيات المياه الجوفية من معظم العناصر

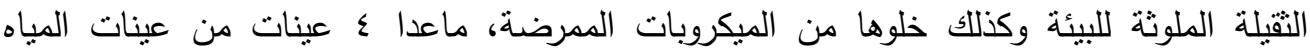
الجوفية والتي ظهر فيها الميكروبات المرضية E. Coli وبذلك يجب التبات الحذر عند استخدام تلك النوعية 26 
J. Environ. Sci.

Institute of Environmental Studies and Research - Ain Shams University

من المياه في رى المحاصيل خاصة محاصيل الخضر والتي تؤكل طازجة (غير مطبوخة). أما

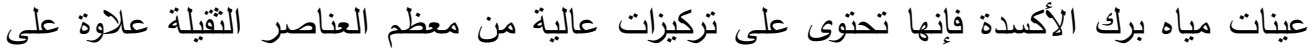

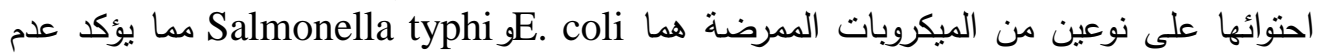

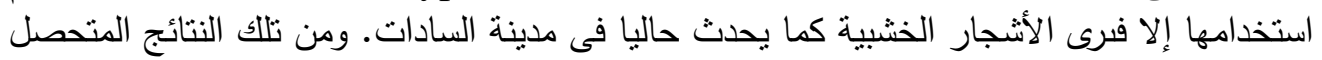
عليها نجد أن معظم المياه السطحية من الرياح الناصري والمياه الجوفية خالية من الملونات الميات المعدنية

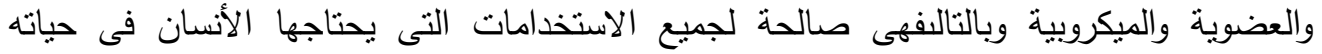

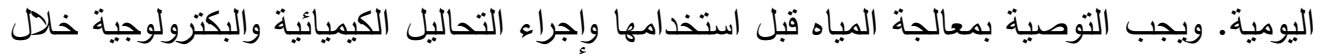
الفترات المتتابعة. الكلمات الدالة: مياه جوفية، مدينة السادات، تلوث كيميائي، تلوث ميكروبي. 